Wojciech Grzegorczyk

Uniwersytet Lódzki

\title{
THE PROBLEMS OF MARKETING PERFORMANCE MEASUREMENT
}

The presented article deals with the problems of marketing performance measurement. In order to measure marketing performance we should determine the costs of marketing activities as well as the volume of revenues generated in the process of their implementation. There are different indicators that can be used to determine the effectiveness of marketing decisions (activities), the one of particular importance being Return on Marketing Investment. ROMI is defined as a financial surplus generated by a marketing investment in relation to the costs incurred in the process of this investment (undertaking). Marketing performance measurement is strictly related to the concept of marketing control. In order to avoid potential overlapping of marketing control and marketing research it is of key importance to precisely define the notion of 'marketing control' and the scope of its content.

Key words: marketing performance, marketing effectiveness, marketing control, marketing costs, marketing research

\section{Introduction}

The aim of this article is to present the author's proposals concerning the evaluation of marketing costs and different options of the use of marketing control for the purposes of marketing performance measurement. The article is intended to eliminate ambiguities both in the terminology of marketing research and marketing control and the scope of content of these two notions. In order to achieve that the author conducted research based on literature in the field of marketing and marketing control.

\section{The costs of the marketing activities}

The first budget elements to be determined are marketing expenditures that constitute marketing costs. An extremely important element of the marketing budget, apart from the costs of marketing activities, are the revenues generated from the sales resulting from a specific marketing activity. Therefore it is necessary to estimate the market potential and to conduct a forecast of revenues generated from the sales of particular products. However, as far as marketing costs are concerned, there are problems to define their level clearly arising from the fact that it is difficult to determine the scope of marketing activities and, as a result, the scope of marketing costs. According to some practitioners and scholars in the field of management, marketing solely involves promotional activities supporting the sales of products, so marketing costs include mainly the costs of advertising and other promotional activities [Niestrój, 2002; Karasiewicz, 2014]. In this 
approach other marketing activities are largely ignored. The opposite approach towards marketing costs, in contrast, takes into account, apart from expenditures on promotion, all other costs incurred in the process of preparation and implementation of any marketing activities undertaken in a given period of time resulting from the marketing strategy being implemented. They are related to market research, product and price policies, delivering a product to the market and promotional activities. Some of these costs refer to classical marketing activities whereas others are incurred while other company's functions are being performed. The criterion to make a distinction between them can be the place of occurrence, however they can be distinguished in a relatively simple way on the basis of the company's organizational structure as well as the production and commercial processes implemented (e.g. the costs of materials, raw materials, energy, costs of production and sales). The problem of the diverse character of marketing costs has been pointed out by R. Niestrój, who presented a relevant proposal of dividing them into two categories. The first category includes the costs related to the marketing system functioning, whereas the other category comprises the costs related to the marketing system development. The costs of the marketing system functioning consist of fixed and variable costs. Fixed marketing costs include the costs of the marketing department functioning on a day-to-day basis (e.g. the employees' salaries, costs to provide equipment and buy professional literature and trade press for the marketing department, the costs of research surveys, etc.), whereas variable costs involve the costs of the implementation of particular undertakings resulting from the adopted marketing strategy. As it also follows from the above list, some of the marketing costs are incurred in the production process (e.g. the costs of the concept preparation and trial production). The costs of market testing can also be classed in the category of costs related to production. The remaining costs result from promotional and distributional (sales-related) activities.

Another extremely important element of the marketing budget, in addition to the costs of marketing activities, is the sales revenues generated from particular undertakings. Therefore, it is necessary to determine the market potential and prepare revenue forecasts from the sales of particular products. Depending on the required accuracy of the sales forecast we can use the terms of sales projections, predictions and forecasts. A sales projection involves transferring of the past and present conditions into the future (extrapolation). A sales prediction refers to determining the future sales volume on the basis of the discovered relations between sales and factors affecting sales performance. A sales forecast is drawn up on the basis of projections and predictions as well as anticipating the factors that are not measurable and it can be prepared with the use of qualitative and quantitative methods [Dębski, 1998; Dittman, 2008].

The other category of marketing costs refers to the development of marketing activities and the marketing system in an enterprise as a result of long-term decisions. It may include, for example, a change or development of the company's IT system, development or expansion of the company's distribution networks on the domestic market and abroad (building storage and warehousing facilities, wholesale outlets, retail stores). The costs incurred in the process of marketing development as well as expenditures on current marketing activities should be treated as a marketing investment that results in the increase of an enterprise's business value and the value of its assets. 
They could be both tangible and intangible assets, such as modern IT systems, company distribution networks, market shares, brand awareness and the company's brand image.

\section{Marketing performance}

The fact that marketing outlays are treated as marketing investments means that they have to be measured and that their effectiveness and efficiency have to be determined. The predominant conviction that had been present in marketing literature for many years was that marketing performance measurement was not possible due to the specific character of marketing activities and mutual interrelations between the applied marketing instruments. In consequence, such an approach did not allow determining the interdependence between the company's marketing strategy and its finance. It was only at the beginning of the 1990s when the debate concerning the efficiency of marketing strategies and the interdependence between marketing and finance started.

The process of marketing management involves the analysis of an enterprise and its environment, determination of marketing objectives, marketing strategy and the applied marketing instruments as well as implementation of the marketing strategy. The last stage of this process refers to marketing control and it is at this stage that the extent to which the assumed marketing objectives and efficiency have been achieved is being examined. The comparison of the achieved objectives in relation to particular undertakings with the ones planned will enable to determine the extent to which the assumed plans have been realised, which means it will determine their effectiveness. On the other hand, the comparison of the outlays on marketing undertakings with the effects that they have brought about will enable to determine their efficiency. Marketing efficiency can be measured in relation to different aspects. It can refer to:

the company's market position - e.g. its sales volume, market share,

buyers - e.g. customer satisfaction, product image,

marketing assets - e.g. brand value, customer value, distribution network.[Karasiewicz, Skorek, Wilczak, 2006]

The literature concerning marketing performance still raises the problem of difficulties involved in examining individual impact of each of the applied marketing instruments on the realization of the assumed objectives, which is fully justifiable, as they are applied jointly. Moreover, the effects of the undertaken activities are very frequently postponed in time.

There are various kinds of indicators used to measure marketing performance. They refer to all kinds of marketing activities undertaken in the areas of product policy, pricing, distribution and promotion [Kozielski 2006]. The indicator that is most frequently used to measure both the short-term and long-term results of marketing activities, however, is the Rate of Return on Marketing Investment. It is a typical indicator of financial character. There are even opinions, presented in some publications on the subject, that it is the primary indicator used to evaluate investment undertakings in the area of marketing. [Lenskold 2004] It enables us to relate the total costs of a particular marketing investment to the total profit that it generates. A marketing investment, therefore, includes all the costs of a given undertaking resulting from a marketing plan, which are subject to risk, whereas the whole financial surplus that can be assigned to this investment is a return on this investment. If an investment concerns a 
market launch of a new product the gross margin is calculated by deducting the costs directly related to sales from the revenues. The costs strictly related to marketing fall under the category of investment involved in a given undertaking. In relation to the development of a new product these costs involve personnel costs necessary to prepare a marketing plan for a new product, the costs of prototype development, trial production and new product testing, the costs of promotional activities and the costs related to the delivery of a new product onto the market (distribution).

Return on Marketing Investment is thus a fraction in which the difference between the gross margin and the marketing investment is a numerator, while the marketing investment is a denominator. The gross margin is the difference between the sales revenues and the costs of the products sold including additional costs. The costs of the products sold include both fixed and variable costs of production (materials, raw materials, energy, labour) as well as overheads. A simplified formula presenting Return on Marketing Investment has been given below [Lesnskold 2004]

Return on Marketing Investment $=($ Gross margin - marketing investment $)$ :

Marketing investment $=$ (sales revenues - sales costs - marketing costs of the undertaking) : marketing costs of the undertaking

As it can be seen the use of the rate of Return on Marketing Investment corresponds to the already mentioned principle of treating marketing outlays as an investment.

The rate of Return on Marketing Investment can be also defined as a rate of marketing expenditures (outlays). Its calculation can be related to different time periods (e.g. months, quarters or years), depending on the requirements of marketing analysis. According to the principles of rational behavior the break-even point level of an investment in a company needs to be determined before any strategic decisions have been made and the return on particular marketing investments should be estimated after that. It will enable the company to select a marketing option that will either meet or exceed the assumed break-even point level. Of course, the rate of return on a marketing investment should also be determined after the given undertaking has been realised, mainly in order to compare the quantities that were planned with the ones that were really achieved.

Some marketing activities in an enterprise are being constantly implemented over a long period of time and they support many other marketing undertakings. They are related to the fixed costs of the company's marketing system functioning. Such activities include, among others, the Internet use involving placing advertising messages informing about the company or its product offer, maintaining marketing databases, etc. The costs related to such activities should be allocated in proportion to either all subsequent marketing undertakings or to the most important marketing undertakings, that is the ones that generate the highest proportion of the company's gross margin.

\section{Marketing control and its role in marketing performance research}

As it has already been mentioned, the last stage of marketing management is marketing control. Recently, this stage has been commonly referred to as marketing controlling [Sławińska, 2014]. Questions arise, however, as to the meaning of this term. In 
marketing publications the last stage of the marketing management process called marketing controlling is limited to examining the extent to which the assumed objectives have been reached and analysing the efficiency of marketing undertakings. The results of these examination are supposed to be used to adjust the content of particular stages of marketing management in subsequent periods of time.

In the literature concerning marketing control itself; however, it is defined in much broader terms. Functionally, marketing control is defined as a data-feeding system which supports the process of the company's management through coordination, planning, control and analysis [Godziszewski 1990; Nowak, 2011]. Institutionally, it is equivalent to management accounting. Management accounting deals with the collecting, processing and reporting of the company's data for the purposes of the management process in the company. [Nowak, 2000]. According to the IFAC (The International Federation of Accountants) definition, management accounting is a process of collecting, analysing, interpreting and communicating information of not only financial but also non-financial character [Nita, 2008]. Controlling, therefore, involves acquiring information from accounting and creating an information system supporting the processes of planning, controlling and analysing based on this information within a company. According to the above presented definitions the content of controlling/management accounting largely overlaps with the content of the Marketing Information System. The Marketing Information system (MIS) is a coordinated system of teams of people and their activities as well as tools and procedures to collect, process, analyse and store the information necessary to take marketing decisions [Karcz, Kędzior, 1997; Kotler 1994]. It consists of four subsystems of: archive resources, marketing intelligence, marketing research and marketing decisions support. Two of these subsystems: marketing research and marketing intelligence are particularly destined to collect and analyse the information about a company and its environment. They collect, among others, the financial information about a company with the use of the company's financial documents (balance sheets, profit and loss accounts, cash flow statements) as well as the financial information about the company's competitors acquired from various sources. It is evident then that the Marketing Information System (MkIS) functions overlap with those of controlling/ management accounting. This problem has not been addressed yet by the authors dealing with the issues of marketing and controlling. [Nowak, 2011]. Some authors of publications concerning controlling claim that MkIS constitutes an underlying basis for the functioning of marketing control without providing any in-depth analyses. These publications do not make a distinction between controlling and MkIS either and although controlling as such is presented in functional terms, the practical recommendations to use it indicate that it is perceived as management accounting.

In practice marketing managers applying MkIS are able to evaluate and interpret the acquired information, including the information related to finance. In order to achieve a permanent competitive edge, however, companies have to collaborate with controlling, management accounting and marketing managers. Collaboration of this kind should involve providing marketing managers with the financial information obtained as a result of the analysis of the financial documents of the company and its competitors (balance sheets, profit and loss accounts, cash flow statements.) This information, among others, is used to determine the position of the company and its major 
competitors in a particular economic sector and can indicate a potential necessity of changes in the company's marketing strategy.

It seems that the problem of an overlap between the content of Marketing Information System and controlling/management accounting can be resolved in a number of different ways. In order to do that the company should put controlling/management accounting in the right place of its organizational structure as we deal here with the Management Information System, which, according to the functional approach, consists of several particular information systems such as Marketing, Production, Research and Development, Human Resources and Finance as well as the influx of information from outside the company [Kaczmarczyk, 1999]. It can be assumed then that the Information System created by management accounting/controlling is part of the Management Information System called the Financial Information System. We can also assume that that it is a new additional element of the Management Information System under the name of the System of Management Information, along with the existing Financial Information System. Placing controlling within the Financial Information System or making it a separate independent element of the Management Information System means that all functions in the company are equally important and strongly engaged in the implementation of the company's strategic aims. It is significant in view of the fact that ecently published accounting literature has introduced the term of a business partner, i.e. management accounting specialist. According to the authors using this term the business partner should be placed in the centre of the company's organizational processes and the business partner's activity should be regarded as the highest form of business partnership. Such a business partner is defined as a financial leader be to lead the company's managers in order to achieve the company's long-term goals [Kabalski, Sobańska,2014]. Such an approach may result in a potential clash between different functions in the company.

Marketing control can be also regarded as the last stage of the company's marketing management process, which means that in fact it only deals with marketing performance research. In this case we use selected indicators of marketing performance effectiveness referring to all the aspects of marketing activities and the content of marketing control and that of the Marketing Information System do not overlap then.

\section{Summary}

Marketing performance research is necessary to make right marketing decisions. The company uses different sorts of information for that purpose but the financial information and the financial indicators concerning the company's marketing performance are becoming of particular importance. When accounting, finance and marketing experts examine the company's performance separately the content of their research and their activities related to marketing performance evaluation may overlap. It appears that in order to avoid such a situation two different options can be proposed. The first of them is to place the System of Management Information within the Management Information System. The other option is to treat marketing performance research as a stage of marketing control that can be implemented as a result of marketing research. 


\section{Bibliography}

Dębski W., Prognozowanie sprzedaży, CIM Warszawa 1998;

Dittmann P., Prognozowanie w przedsiębiorstwie, Wolters Kluwer, Kraków 2008

Godziszewski J., Controlling-system koordynacji przedsiębiorstwa, Przegląd Organizacji, nr 89/1990

Kabalski P., Sobańska I., Partner biznesowy-nowa rola specjalisty od rachunkowości zarządczej, Przegląd Organizacji, nr 7/2014

Kaczmarczyk S., Badania marketingowe. Metody i techniki, PWE, Warszawa 1999

Karasiewicz G., Wydatki marketingowe polskich przedsiębiorstw, Marketing i Rynek nr 8/2014

Karasiewicz G., Skorek M., Wilczak A., Efektywność działań marketingowych a marketingowa marża brutto, w: Ekspansja czy regres marketingu, PWE, Warszawa 2006,

Karcz K., Kędzior Z. Badania marketingowe w praktyce, PWE, Warszawa 1997,

Kotler Ph. Marketing, Analiza, planowanie, wdrażanie i kontrola, Gebethner i S-ka, Warszawa 1994

Kozielski R. (red.) Wskaźniki marketingowe, Woters Kluwer, Kraków 2006

Lenskold D., Pomiar rentowności inwestycji marketingowych, Wolters Kluwer Kraków 2004

Niestrój R., Finansowe aspekty planowania marketingowego, w: Marketing , koncepcje, badania, zarządzanie, PWE Warszawa 2002

Nita B., Rachunkowość w zarządzaniu przedsiębiorstwem, Wolters Kluwer, Kraków 2008,

Nowak E., Rachunkowość zarządcza strategiczna i operacyjna, Controlling i rachunkowość Zarządcza, $\mathrm{nr}$ 5/2000

Nowak E., Controlling w działalności przedsiębiorstwa, PWE Warszawa 2011

Sławińska M., Marketing jako koncepcja zarządzania -trendy rozwoju, Marketing i Rynek, $\mathrm{nr} 8 / 2014$

\section{Problemy pomiaru rezultatów dzialań marketingowych}

\section{Streszczenie}

Prezentowany artykuł dotyczy problemów badania efektywności działań marketingowych. W tym celu należy więc określić koszty przedsięwzięć marketingowych oraz osiagane przychody z tytułu realizacji tych przedsięwzięć. Ustalenie efektywności podejmowanych decyzji (przedsięwzięć) marketingowych można osiagnąć przy pomocy różnych mierników, wśród których szczególne znaczenie ma wskaźnik zwrotu z inwestycji marketingowej. Jest to nadwyżka finansowa ponad inwestycję, którą można jej przypisać w relacji do kosztów tej inwestycji(przedsięwzięcia). Pomiar efektywności jest ściśle związany z pojęciem controllingu marketingowego. Istotne znaczenie ma sprecyzowanie jego pojęcia i zakresu treściowego dla wyeliminowania ewentualnych kolizji z badaniami marketingowymi.

Słowa kluczowe: efektywność marketingu, controlling marketingowy, koszty marketingu, badania marketingowe.

\section{Informacje o autorze:}

Prof. zw. dr hab. Wojciech Grzegorczyk

Uniwersytet Łódzki

Wydział Zarządzania

ul. Matejki 22/26, Łódź

e-mail: Grzegorczyk@uni.lodz.pl 